\title{
EXPERIENCE OF USING THE MONTE-CARLO METHOD IN DETERMINING OPTIMAL PLASTER COMPOSITIONS WITH IMPROVED STRENGTH PROPERTIES
}

\section{Khrystyna Moskalova}

Scientiffic paper / Znanstveni rad

Odessa State Academy of Civil Engineering and Architecture, Department of Processes and apparatuses in the technology of building materials, Assistant Professor

\section{Aleksej Aniskin}

University North, Department of Civil Engineering, Senior Lecturer

Corresponding author: krisogasa@gmail.com

\begin{abstract}
Considering that modern building materials impose increasing performance requirements, it is necessary to expand the range of building materials and improve their multicomponent composition. The effects of polymer and porous components (expanded perlite sand and carbonate filler - limestone-shell rock) in cement-lime light plaster on the physico-mechanical properties of the mixtures under equal workability conditions of mixtures are analyzed based on experimental-statistical modeling. The results of the physico-mechanical and operational experiments confirm the rationality of using porous fillers and additives to improve certain specific properties of the final product. The so-called Monte-Carlo method is implemented for determining an optimal composition of multicomponent cement-lime light plaster, based on multivariate statistical modeling and iterative random scanning of property fields. According to the results of the computational experiment, a composition that reduces the number of expensive mixture components and improves the physical and mechanical characteristics of the resulting composition is selected.
\end{abstract}

Keywords: cement-lime light plaster; polymer; experimental-statistical modeling; Monte-Carlo method

\section{PRONALAŽENJE OPTIMALNIH SASTAVA ŽBUKE S POBOLJŠANOM ČVRSTOĆOM METODOM MONTE-CARLO}

Sažetak: Uzimajući u obzir činjenicu da se za moderne građevinske materijale postavljaju sve veći zahtjevi, potrebno je proširiti asortiman građevinskih materijala i poboljšati njihov višekomponentni sastav. $\mathrm{Na}$ bazi eksperimentalno-statističkog modeliranja analiziran je utjecaj polimernih i poroznih sastojaka (ekspandirani perlitni pijesak i karbonatno punilo - biogena vapnenačka stijena) lake cementne žbuke na fizikalno-mehanička svojstva sastava, uz uvjet jednake obradivosti. Rezultati ispitivanja fizikalno-mehaničkih i operativnih svojstva potvrdili su racionalnost upotrebe poroznih punila i aditiva za poboljšanje određenih specifičnih svojstava konačnog proizvoda. Kako bi pronašli optimalan sastav višekomponentne cementno-vapnene žbuke, provedena je Monte Carlo metoda zasnovana na višedimenzionalnom statističkom modeliranju s iterativnim slučajnim pretraživanjem polja svojstava. Prema rezultatima računskih pokusa odabiru se spojevi u kojima se smanjuje udio skupih komponenti smjese i poboljšavaju fizičko-tehnološke karakteristike dobivenog sastava.

Ključne riječi: cementno-vapnena žbuka; polimer; eksperimentalno-statističko modeliranje; Monte Carlo metoda

Moskalova K., Aniskin A. 
Experience of using the Monte-Carlo method in determining optimal plaster compositions with improved strength properties

\section{INTRODUCTION}

At present, building technologies based on modified dry mixtures are used extensively, owing to a number of advantages: minimum technological operations for rendering dry mixtures into a working condition (water-mixing); reduction of waste solutions by $5-7 \%$ owing to the use of plasticizers and water-retaining additives; stability of quality properties of dry mixes and mortars on the basis of dry mixes as a result of exact component dosage and mixing efficiency; increases in labor productivity of 1.5-3 times owing to an improvement in the plastic properties of mortar and mechanical work performance; and a reduction of 10-15\% in transportation costs and improvement of work quality, while the labor intensity of technological processes is reduced [1].

\section{MATERIALS AND METHODS}

Modern dry building mixtures are multicomponent; therefore, an analysis on the effects of the composition on mixture properties can be carried out using computer material science tools, based on the property plains concept [2]. To describe the behavior of mixtures using computer tools, an experiment was carried out according to the optimal 18-points plan [3]. Cement-lime light plaster based on perlit loading was employed as a baseline mixture, and the composition consisted of a polymer-cement mixture containing perlite sand, Vinnapas redispersible powders, and water-retaining and air-entraining additives [4,5]. Four composition factors were varied (relative to 1000 weight parts (w.p.) of a plaster):

$X_{1}$ : powdered to $S_{s s}=400 \mathrm{~m}^{2} / \mathrm{kg}$ limestone rock, $80 \pm 20$ w.p.;

$\mathrm{X}_{2}$ : expanded perlite sand of mark 100, $40 \pm 10$ w.p.;

$X_{3}$ :- methylhydroxyethylcellulose Tylose 60010 (water-soluble, non-ionic cellulose ethers), $1.15 \pm 0.15$ w.p.;

$\mathrm{X}_{4}$ : polymer redispersible powder Vinnapas RE $5034 \mathrm{~N}$ (copolymer of vinyl chloride, ethylene, and vinyl laurate), 1.5 \pm 0.5 w.p.

Based on the experimental results obtained, four-factor experimental-statistical (ES) models were constructed to describe the explored quality criteria. The COMPEX system, designed by the Odessa State Academy of Civil Engineering and Architecture, is effective for the construction of ES models and was used to process the ES model data, optimize, and make engineering decisions. The COMPEX program is compatible with Windows. It enables the construction of models with a generated experimental error $S$ and calculation of generalized indices of the material property fields, among others. The fields described by these models can be characterized by generalizing indicators. The generalizing exponents of the property $Y$ in the boundaries of the field under study are the minimum, $Y_{\min }$, and maximum, $Y_{\max }$, levels, as well as their respective coordinates, $X_{\min }$ and $x_{\max }$ (Table 1).

Table 1 Generalized parameters of plaster mortar

\begin{tabular}{|c|c|c|c|c|c|c|c|c|c|}
\hline \multirow{2}{*}{\multicolumn{2}{|c|}{ Parameter Y }} & \multicolumn{2}{|c|}{$\rho, \mathrm{kg} / \mathrm{m}^{3}$} & \multicolumn{2}{|c|}{$\mathrm{R}_{\mathrm{A}}, \mathrm{MPa}$} & \multicolumn{2}{|c|}{ Rt.s., MPa } & \multicolumn{2}{|c|}{$\mathbf{R}_{\text {c.s. }}, \mathrm{MPa}$} \\
\hline & & $\min$ & $\max$ & $\min$ & $\max$ & $\min$ & $\max$ & $\min$ & $\max$ \\
\hline \multicolumn{2}{|c|}{$Y_{\exp }$} & 1046 & 1333 & 0.08 & 0.49 & 1.83 & 3.49 & 4.08 & 8.8 \\
\hline \multirow{4}{*}{ 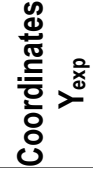 } & $\mathrm{x}_{1}$ & 1 & -1 & -1 & -0.6 & 1 & -0.5 & 1 & -0.7 \\
\hline & $\mathrm{x}_{2}$ & 1 & -1 & 1 & 1 & -1 & 0.1 & -1 & 1 \\
\hline & $x_{3}$ & 1 & -1 & -1 & 0.7 & 1 & 0.1 & 1 & 0.5 \\
\hline & $\mathrm{X}_{4}$ & -1 & -1 & -1 & 1 & -1 & 0.2 & -1 & 0.7 \\
\hline \multicolumn{2}{|c|}{$\Delta Y$} & \multicolumn{2}{|c|}{287} & \multicolumn{2}{|c|}{0.41} & \multicolumn{2}{|c|}{1.66} & \multicolumn{2}{|c|}{4.72} \\
\hline \multicolumn{2}{|c|}{$\delta Y$} & \multicolumn{2}{|c|}{1.27} & \multicolumn{2}{|c|}{6.1} & \multicolumn{2}{|c|}{1.9} & \multicolumn{2}{|c|}{2.2} \\
\hline \multicolumn{2}{|c|}{ S } & \multicolumn{2}{|c|}{28.5} & \multicolumn{2}{|c|}{0.03} & \multicolumn{2}{|c|}{0.166} & \multicolumn{2}{|c|}{0.37} \\
\hline
\end{tabular}

To select a desirable multicomponent plaster mixture, a technique based on multifactorial statistical modeling and iterative random scanning of property fields is implemented using the Monte-Carlo method. A multi-criteria search of the optimal mixture ratio enables determination of a guaranteed recipe and technological solutions of

Moskalova K., Aniskin A. 
Experience of using the Monte-Carlo method in determining optimal plaster compositions with improved strength properties

different levels: optimal and compromise. A computer search for compromise solutions has no restrictions on the number of factors $k$, number of restriction criteria $M\left\{Y_{\text {norm }}\right\}$, and optimality criteria $M\left\{Y_{\text {opt }}\right\}$.

\subsection{Analysis of the effect of composition components on mixture properties using ES-modeling}

Because heat-insulating plastering mixtures are characterized by low density [6], to provide a comparative analysis, the diagrams in Figure 1 reflect the effects of the amount of ground limestone and perlite on the strength characteristics of the plaster composition. The diagram was created for compositions with a density not exceeding $1200 \mathrm{~kg} / \mathrm{m}^{3}$; such a low density was achieved for compositions with a maximum methyl hydroxyethyl cellulose $\left(\mathrm{x}_{3}\right.$ $=+1)$ and Vinnapas redispersible powder $\left(x_{4}=+1\right)$ content.

As can be seen from the diagrams provided, the strength characteristics of the studied plaster mixtures increase with the contents of fine aggregate fillers. Therefore, within the factorial experimental space, under the influence of varying composition factors, the compressive strength $\left(R_{\text {c.s. }}\right)$ of the plasters becomes double, from 4 to $8 \mathrm{MPa}$. In this case, the most resistant compositions are those with an average amount of limestone (approximately 80 w.p.).

The concentrations of Vinnapas and perlite have a significant effect on transverse strength. If the redispersible powder content is at a maximum ( $x_{4}=2$ w.p.), minimum values of $R_{t . s .}$ are achieved with a low perlite content, and accordingly, by increasing this factor, the strength also increases. Polymer powders create elastic films in the pores of the solidified compositions; therefore, modified mixtures can obtain high tensile strength. The spatial system of polymer films, formed inside the cement stone, appears as a micro-damping element that facilitates the relaxation processes of the system.
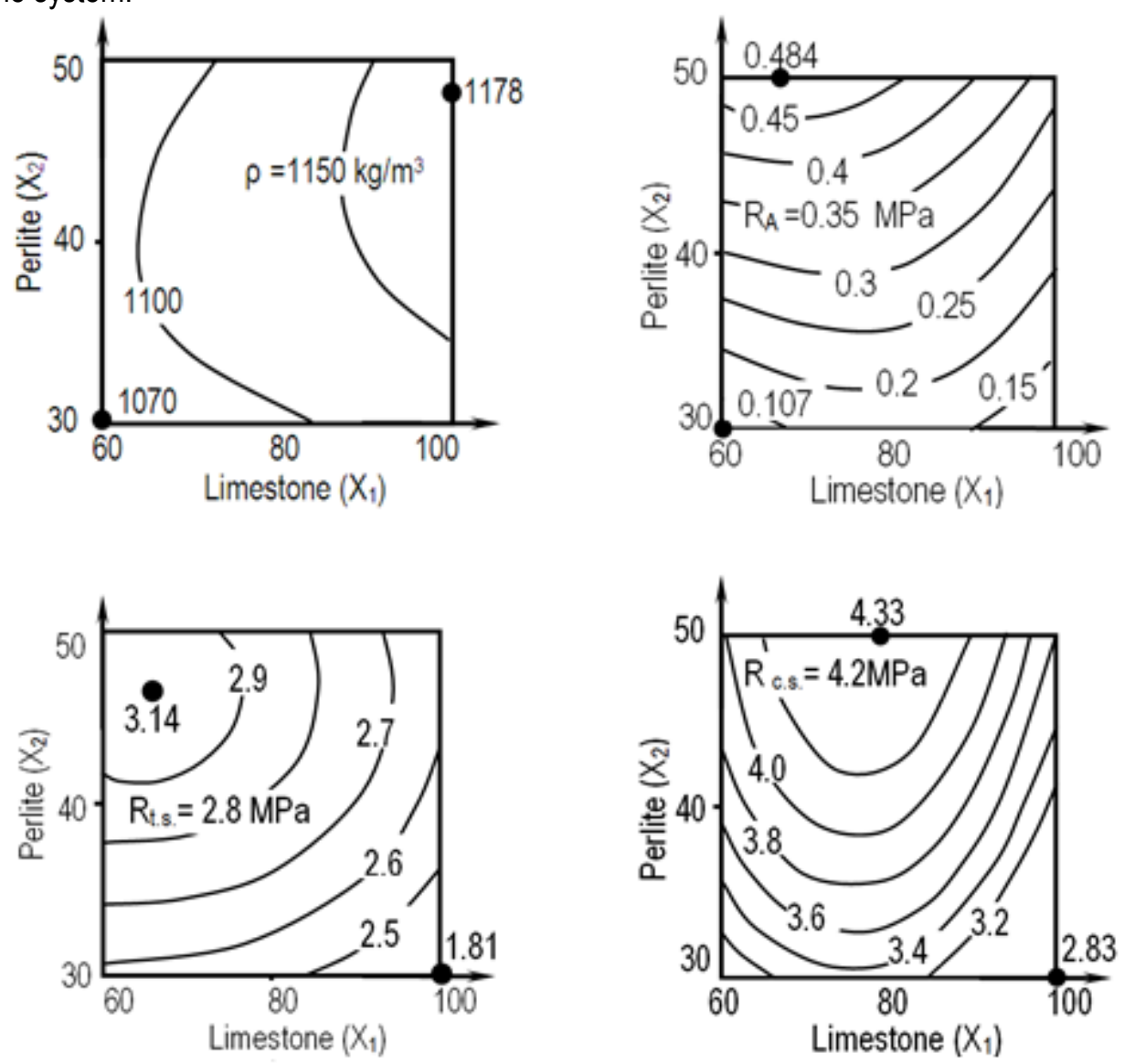

Figure 1 Influence of limestone-perlite filler on plaster strength characteristics

Moskalova K., Aniskin A. 
Experience of using the Monte-Carlo method in determining optimal plaster compositions with improved strength properties

The adhesive strength $\left(R_{A}\right)$ is also significantly affected by the amount of Vinnapas redispersible powder $\left(x_{4}\right)$ and perlite $\left(\mathrm{x}_{2}\right)$. When the concentration of factor $\mathrm{x}_{2}$ is increased to the maximum, the adhesive strength increases by an average of $0.2 \mathrm{MPa}$.

\subsection{Search for region of optimal compositions}

Because practically all the composition properties studied did not go beyond the recommended or normalized range [5], the compressive strength $R_{\text {c.s. }} \geq 7 \mathrm{MPa}$, flexural strength $R_{\text {t.s. }} \geq 2 \mathrm{MPa}$, and adhesion $R_{A} \geq 0.3 \mathrm{MPa}$ were selected as optimization factors.

The objective of this study was to maximize the strength characteristics, while striving to ensure that the composite density did not exceed $1200 \mathrm{~kg} / \mathrm{m}^{3}$. The median levels of the model-determined field of properties were taken as starting points for optimization and the search for a compromise. For the maximized factors $R_{\text {c.s. }}, R_{\text {t.s. }}$, and $R_{A}$, these values are, respectively $R_{\text {t.s.M }}=0.5\left(R_{\max }+R_{\min }\right)=0.5(3.48+1.83)=3.07, R_{\text {c.s. }}=0.5\left(R_{\max }+R_{\min }\right)=$ $0.5(8.76+4.08)=7.38$, and $R_{\text {A.M. }}=0.5\left(R_{\max }+R_{\min }\right)=0.5(0.48+0.08)=0.27$. The change in the interval of factors during the computational experiment is illustrated in Figure 2.
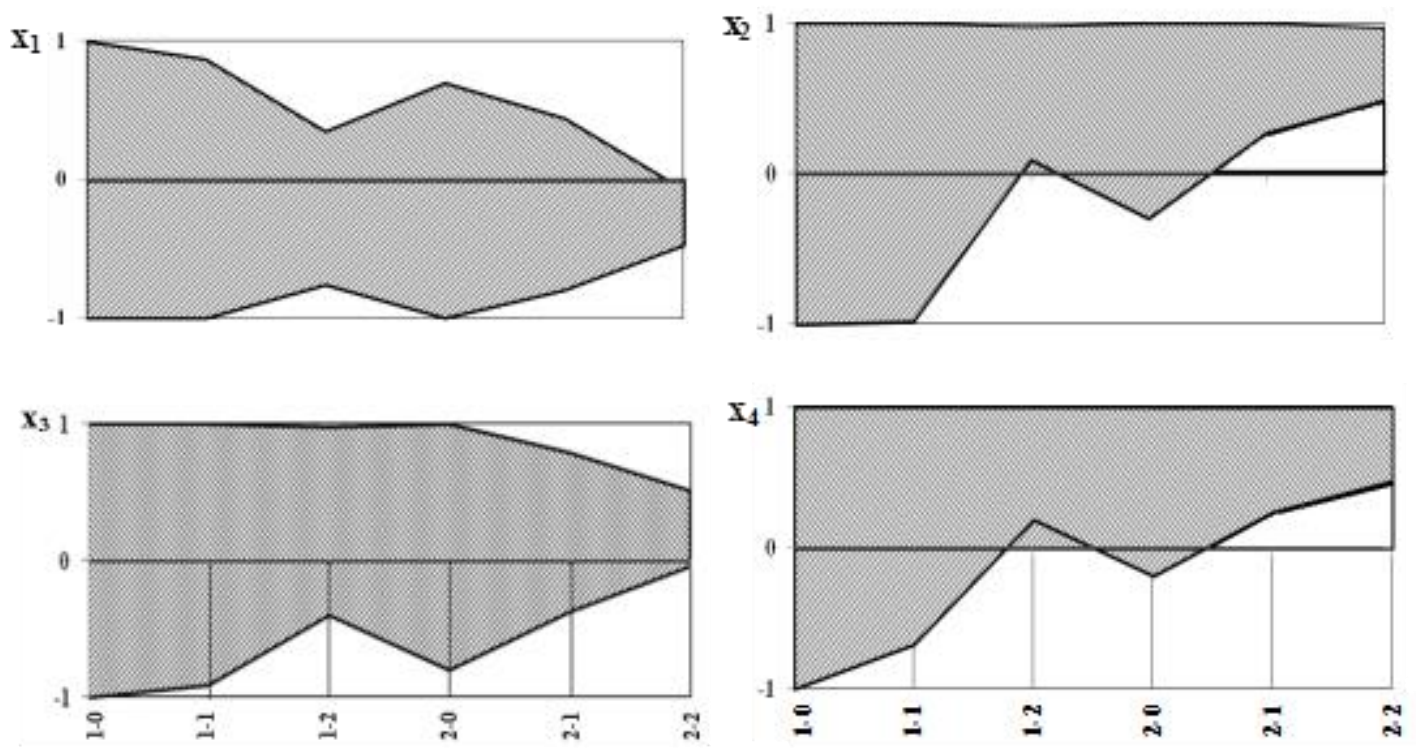

Figure 2 Variation ranges of four normalized factors in computational experiment

During the first stage of the first iteration "1-0", $\mathrm{N}$ random, uniformly distributed vectors $\mathrm{x}$ are generated in the field region, in which case, the area consists of 1.016 compositions. The range of each factor $\left(x_{1}-x_{4}\right)$ is from -1 to +1 . Those compositions with levels of criteria, $R_{c . s .}, R_{t . s .}$, and $R_{A}$, satisfying the standard requirements are selected for further analysis, while the remainder ("unsatisfactory" formulations by the standard) are deleted. Thus, step "1$1 "$ forms an acceptable region, where the limit level of optimized criteria coincides with the corresponding median. After the first iteration, 235 compositions remain in the acceptable region, with the following factor values: $R_{t . s .}>3$ $\mathrm{MPa}, \mathrm{R}_{\mathrm{c.ss}}>8 \mathrm{MPa}$, and $\mathrm{R}_{\mathrm{A}}>0.35 \mathrm{MPa}$.

During stage "1-2", a step-by-step approach to the maximum of $R_{\text {c.s. }}=8.75 \mathrm{MPa}, \mathrm{R}_{\mathrm{t.s.}}=3.49 \mathrm{MPa}$, and $\mathrm{R}_{\mathrm{A}}=$ $0.49 \mathrm{MPa}$ is carried out. At this experimental stage, the search region was reduced to 53 compositions (Figure 2). It is difficult to conduct a further search for the optimum during the first iteration. Figure 3 shows the optimization results at this stage, where the criteria levels are better than the median $\left(R_{c . s}=8>R_{c . s} \mathrm{M}=7.38 \mathrm{MPa}\right.$ and $R_{A}=0.35>$ $\mathrm{R}_{\mathrm{AM}}=0.27 \mathrm{MPa}$ ). 
Experience of using the Monte-Carlo method in determining optimal plaster compositions with improved strength properties
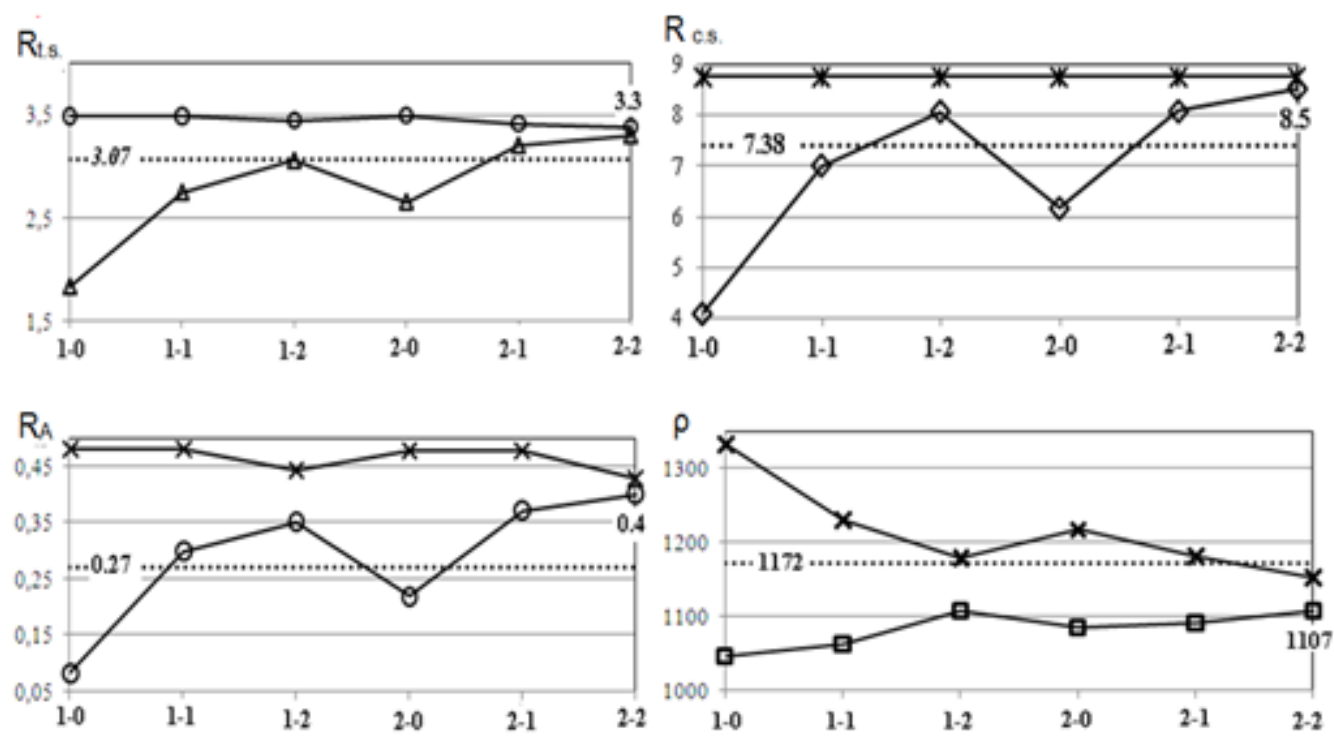

Figure 3 Changes in optimized properties during computational experiments

The iterative process should continue, generating 1000 new points in the expanded analysis (Figure 3), by considering step $\Delta_{1} x_{i}$ of the compromise region. The focus during the second iteration (stage 1-2) is on the search for compositions providing maximum strength characteristics in the low-density region.

During stage "2-2", the boundaries of the region of remaining compositions (Figure 2) became much closer. In these compositions, the boundaries of the optimized criteria ranges (Figure 3 ) are practically closed, and the search process can be stopped.

\section{CONCLUSION}

The mechanical strength of the mixtures changes more than twice when the factor levels change from minimum to maximum. Replacing a portion of the perlite with limestone increases the compressive and transverse strength, the most stable composition being that with an average amount of limestone. Adhesion of the plaster mixtures to the base is significantly increased by increasing the amount of Vinnapas redispersive powder, which purposefully provides this property. At the maximum Vinnapas dosage, an adhesion level above $0.4 \mathrm{MPa}$ is reached.

According to the computational experiment results, compositions with a reduced amount of components can be selected, providing positive economic effects. Usually, this economic effect is expressed in a money equivalent, and it is also convenient to compare the positive effects obtained from the experiment with a percentage. Therefore, by reducing the amount of limestone by $35 \%$, the dosage of perlite by $10 \%$, the amount of water-retaining additives by $8 \%$, and the content of redispersible powder by $5 \%$ in relation to the base mixture, the cost of a ton of dry light plaster can be reduced by an average of $10 \%$. These composites are expected to have the following quality criteria values: density $\rho=1130 \mathrm{~kg} / \mathrm{m}^{3}$; compressive strength $R_{\text {c.s. }}=8.8 \mathrm{MPa}$; transverse strength $R_{\text {t.s. }}=3.3 \mathrm{MPa}$; and adhesion $\mathrm{R}_{\mathrm{A}}=0.4 \mathrm{MPa}$. Furthermore, the physical and mechanical characteristics of this composition were improved in comparison with the requirements. 
Experience of using the Monte-Carlo method in determining optimal plaster compositions with improved strength properties

\section{References}

[1] Dilger U. 2000: Planning and construction of production plants for dry mortars, Dry building mixtures of the XXI century: technology and business, Proc. Int. Conf., Saint-Petersburg, pp. 46-52.

[2] Voznesensky V.; Lyashenko T. 1998: Experimental-statistical modelling in computational materials science, Astroprint, Odessa.

[3] Voznesensky V.; Lyashenko T. 1999: Computational experiments with experimental-statistical models for composites on alkaline binders, Alkaline Cements and Concretes, Proc. 2nd Int. Conf., Kyiv, pp. 507-517.

[4] Popov O.; Moskalova K. 2016: An analysis of the technological properties of facilitated plaster solutions made from dry building mixes, Tehnički glasnik, 10 (3-4), pp. 102-105.

[5] Soha V.; Voznesensky V.; Karapuzov E.; Moskalova K.; Krovyakov S. 2010: Properties of lightweight plasters from dry building mixtures with perlite and limestone fillers, Building materials and products, 3, pp. 11-14.

[6] Runova R.; Nosovskyy Yu. 2007: Tekhnolohiya modyfikovanykh budivel'nykh rozchyniv, KNUBA, Kyiv (In Ukranian). 